Een stralende lach 


\section{Een stralende lach}

Anna Beeftink

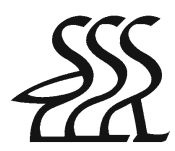

Bohn Stafleu van Loghum

Houten 2007 
(C) Bohn Stafleu van Loghum, 2007

Alle rechten voorbehouden. Niets uit deze uitgave mag worden verveelvoudigd, opgeslagen in een geautomatiseerd gegevensbestand, of openbaar gemaakt, in enige vorm of op enige wijze, hetzij elektronisch, mechanisch, door fotokopieën of opnamen, hetzij op enige andere manier, zonder voorafgaande schriftelijke toestemming van de uitgever.

Voor zover het maken van kopieën uit deze uitgave is toegestaan op grond van artikel I6b Auteurswet $19 \mathrm{I} 2 \mathrm{j}^{\mathrm{O}}$ het Besluit van 20 juni 1974, Stb. 351, zoals gewijzigd bij het Besluit van 23 augustus I985, Stb. 47I en artikel I7 Auteurswet I9I2, dient men de daarvoor wettelijk verschuldigde vergoedingen te voldoen aan de Stichting Reprorecht (Postbus 305I, 2130 KB Hoofddorp). Voor het overnemen van (een) gedeelte(n) uit deze uitgave in bloemlezingen, readers en andere compilatiewerken (artikel i6 Auteurswet I9I2) dient men zich tot de uitgever te wenden.

Samensteller(s) en uitgever zijn zich volledig bewust van hun taak een betrouwbare uitgave te verzorgen. Niettemin kunnen zij geen aansprakelijkheid aanvaarden voor drukfouten en andere onjuistheden die eventueel in deze uitgave voorkomen.

ISBN 9789031350247

NUR 887

Ontwerp omslag: ...

Ontwerp binnenwerk: ...

Automatische opmaak: Pre Press, Zeist

Tekeningen: Anna Beeftink

Bohn Stafleu van Loghum

Het Spoor 2

Postbus 246

3990 GA Houten

www.bsl.nl
Distributeur in België:

Standaard Uitgeverij

Mechelsesteenweg 203

20I8 Antwerpen

www.standaarduitgeverij.be 


\section{Voorwoord}

Cosmetische tandheelkunde houdt zich bezig met het verfraaien van het gebit. Je wilt een witter of regelmatiger gebit. Wat is mogelijk? Hoe heten de verschillende behandelingen? Hoe leg ik mijn tandarts uit wat ik wil? Kan het wel wat ik wil? Allemaal vragen die bij je opkomen op het moment dat je de beslissing hebt genomen 'iets aan je tanden te laten doen'. Wachten tot je achterover in de tandartsstoel ligt en vervolgens ervan uitgaan dat je tandarts 'wel weet wat je bedoelt' is niet meer van deze tijd. Misschien denken jullie wel heel verschillend over jouw wensen, en dan kan de behandeling voor beiden op een teleurstelling uitlopen.

Dit boek kan je helpen bij je beslissing. Het zorgt ervoor dat je beter beslagen ten ijs komt en zal veel vragen en onzekerheden bij jou wegnemen. In dit boek worden zeker niet alle mogelijkheden genoemd; er zijn immers altijd veel wegen die naar Rome leiden. Overleg met je behandelaar is dan ook altijd het startpunt voor een geslaagde behandeling.

\section{Indeling van het boek}

Tandartsen denken vaak in oplossingen en technieken; logisch, zo wordt hun dat geleerd op de universiteit. Jij als cliënt ziet die ene bruine tand die je niet wilt, of dat spleetje dat je niet mooi vindt. Omdat dit boek voor jou als cliënt is geschreven, is het ingedeeld met jouw vragen als uitgangspunt.

\section{N LE I D I N G}

De inleiding geeft je achtergrondinformatie over je gebit. Beschreven wordt hoe een gezond gebit eruit hoort te zien, wat gezond met mooi te maken heeft en wat in het algemeen als mooi wordt ervaren. Alles over de normale lengte-, vorm- en kleurverschillen van tanden komt aan bod, zodat je beter met je tandarts kunt overleggen. 
HOOFDSTUK 1

Hoofdstuk I gaat over wat je zelf kunt doen. Alles wat je zelf doet om je gebit gezond te houden is meegenomen. Je tandarts kan je voorlichten over mondgezondheid, hij kan je gebit niet gezond houden voor je, dat kun je alleen zelf. Jij ziet jezelf elke dag, je tandarts zie je één of enkele keren per jaar.

\section{HOOFDSTUK 2}

De meest voorkomende vragen die ik in de praktijk voor cosmetische tandheelkunde tegenkwam, zijn opgesomd in hoofdstuk 2. Bij elk probleem staat beschreven wat mogelijke oplossingen zijn en als het nodig is staat de oorzaak beschreven. Tandheelkundige termen worden alleen genoemd als dat handig is voor het overleg met je tandarts, of om zelf foldermateriaal of andere informatie te kunnen lezen.

\section{HOOFDSTUK 3}

In dit hoofdstuk komen de meest voorkomende cosmetische behandelingen aan de orde, met een verwijzing naar de verschillende problemen uit hoofdstuk 2. Er zijn veel wegen die naar Rome leiden, vandaar ook dat bij elke behandeling de voor- en nadelen worden genoemd. De uiteindelijk gekozen behandeling moet bij jou passen, maar moet ook een behandeling zijn die jouw tandarts 'in de vingers' heeft, deze combinatie zal het beste resultaat geven.

\section{LIJST VAN GEBRUIKTE TANDHEELKUNDIGE TERMEN}

Ten slotte is in dit boek een verklarende woordenlijst opgenomen van in de tandheelkunde veel gebruikte termen. Handig om te ontdekken dat de geheimtaal die je boven je hoofd hoort van tandarts en assistente toch niet zo geheim is, en om bijvoorbeeld je factuur of een verwijsbrief te kunnen lezen.

\section{Dankwoord}

Peter Gijsbers, uitgever, die na een eerste telefoontje al enthousiast was over dit project. Dank je Peter, voor het directe vertrouwen en de prettige samenwerking.

Drs. Hans A. Kelderman, MMSc, bevlogen orthodontist te Zeist, wil ik hartelijk danken voor zijn bijdrage aan het gedeelte over orthodontie en zijn feedback op dit deel van het manuscript.

Lucas van Lier, tandarts. Tijdens mijn studie een van mijn docenten, nu alweer jaren lang bevriend collega. Dank je Lucas, dat ik voor elke foto of vraag je praktijk kon binnenlopen.

Martien Sliedrecht, tandarts-implantoloog te Leersum, dank ik voor 
het enthousiaste delen van zijn praktijkervaring aangaande het implanteren en de prettige samenwerking gedurende de afgelopen jaren.

Dr. Peter J. van Strijen en Frits B.T. Perdijk, kaakchirurgen te Ede, dank voor jullie bijdrage aan het gedeelte over kaakchirurgie en de gecombineerde behandeling orthodontie-kaakchirurgie.

Esmeralda van Vloten, met heel veel plezier hebben we jarenlang samengewerkt in de praktijk voor algemene en esthetische tandheelkunde. Naast je werkzaamheden als assistente leverde je ook vele ideeën voor foldermateriaal voor de praktijk. Deze ideeën hebben een plaats in dit boek gekregen. Esmeralda, mijn hartelijke dank hiervoor.

Hermiona van Zetten, tandarts, collega en vriendin vanaf de studietijd, ben ik veel dank verschuldigd voor het nauwkeurige vakinhoudelijk leeswerk van het manuscript. Hermiona, mijn hartelijke dank voor je collegiale samenwerking en je vriendschap gedurende de afgelopen jaren.

En last but not least mijn geliefde, John van Grunsven, voor zijn aanmoedigingen tijdens het schrijfproces en het kritisch lezen van alweer een manuscript. 


\section{Inhoud}

Voorwoord

Inleiding

I 2

Wat is mooi?

Wat kun je zelf doen?

I.I

Poetsen

22

I.2 Interdentaal reinigen

I. 3

Slechte adem behandelen

28

I. 4

Koortslip behandelen

I. 5

Thuis bleken

30

I. 6

Gebitsonderhoud voor beugeldragers

$2 \quad$ Problemen en hun oplossingen

2.I Ik heb een spleet tussen mijn voortanden 36

2.2 Tussen al mijn tanden zitten spleetjes 44

2.3 Eén voortand staat scheef $5 \mathrm{I}$

2.4 Al mijn tanden staan scheef 60

2.5 Eén voortand is verkleurd 6 I

$2.6 \quad$ Ik heb verkleuring door mijn gehele gebit 66

2.7 Eén tand of kies is raar van vorm 72

2.8 Al mijn tanden zijn anders van vorm $\quad 76$

2.9 Er ontbreekt één voortand 80

2.IO Er ontbreken meer tanden en/of kiezen 83

2.II Eén kroon is lelijk 84

2.I2 Ik heb een probleem met de stand van al mijn tanden $\quad 86$

2.I3 Ik heb veel verschillende restauraties, die niet bij $\begin{array}{ll}\text { elkaar passen } & 87\end{array}$

2.I4 Ik ben lang niet bij de tandarts geweest 89

2.I5 De stand van mijn kaken heeft een ongunstige invloed op mijn profiel 
3 Beschrijvingen van behandelingen 96

3.I Specifiek cosmetisch behandelplan 96

3.2 Ik wil van tevoren zien hoe het gaat worden 98

3.3 Ik wil alleen maar zes mooie voortanden 99

3.4 Uitwendig bleken 99

3.5 Inwendig bleken I 04

3.6 Beslijpen $\quad$ I 08

3.7 Composietopbouw I I 0

3.8 Composietvulling I I 3

3.9 Vastzetten van een afgeslagen tandhoek $\quad$ I 7

3.Io Een kroonrand maskeren met composiet I 20

3.II Composietfacing I 2 I

3.12 Kunststof inlay I 23

3.I3 Behandeling bij indirect gemaakte werkstukken I 26

3.I4 Porseleinen facing I 28

3.15 (Opgebakken) porseleinen kroon I 30

3.16 Brug I 35

3.17 Etsbrug I 37

3.18 Implantaat I 40

3.19 Orthodontie I 45

3.20 Spalken I 50

3.2I Plaatje I 5 I

3.22 Harde splint I 53

3.23 Gecombineerde behandeling, kaakchirurgie en orthodontie I 55

3.24 Volledige (overkappings)prothese I58

Lijst van gebruikte tandheelkundige termen I 6 I

$\begin{array}{ll}\text { Literatuur } & \text { I } 74\end{array}$ 